\title{
Bank Loans, Default Probabilities, and Differential Credit Treatment in Sub-Saharan Banks
}

\author{
Henok Neguse Negash ${ }^{*} \quad$ Hu HongBing \\ School of Finance, Zhongnan University of Economics and Law, Wuhan, China
}

\begin{abstract}
This paper investigates the bank credits, default probabilities, and differential credit treatment in banks of 16 selected Sub-Saharan Africa (SSA) countries by inclusion of annual data of 20 years. The parameters used were obtained from World Bank Development Indicators online database (WDI), Africa Development Bank (ADB), International Monetary Fund (IMF), International Financial Statistics (IFS), and Regional Economic Outlook. By mitigating the problems of spurious causality and unobserved heterogeneity, panel estimation techniques overcome common weaknesses of most cross-country approaches. Panel estimation techniques often give all countries, either small or large, an equal weighting since they are assumed to be homogeneous and the coefficients represent only average relationship, which may or may not apply to individual countries in the sample. Following Arellando and Bond (1991) and as later used by Christopoulous and Tsionas (2004), and Baltagi et al. (2008) a dynamic Generalized Method of Moments (GMM) is applied in the assessment. A dynamic panel estimator allows for the exploitation of time series variations in the data, accounts for unobserved country specific effects, allows for the inclusion of lagged variables as regressors, and controls for endogeneity of all explanatory variables.
\end{abstract}

Keywords: Bank Loans, Capital Adequacy, Default Probabilities, Differential Credit Treatment, Sub-Saharan Africa Banks

DOI: $10.7176 /$ RJFA/11-14-04

Publication date:July $31^{\text {st }} 2020$

\section{Introduction}

The overall depth and financial sophistication of the banking sectors in sub-Saharan Africa (hereafter SSA) is still in its growth stage by global standards. The banks in the region are generally well-capitalized and profitable but they tend to focus most of their lending activities to finance governments and large corporations. However, the bank loans in the region are limited to mainly governments. According to the World Bank report of "Making Finance Work for Africa" (Honohan and Beck 2007, Beck et al, 2009), businesses and households state that they are financially constrained because banks will not lend to them due to the categorization of the banks to these customers as less creditworthy debtors. Therefore, SMEs and some large domestic corporations do not have access to the available bank loans. Bank credits to private and public sectors is subject to credit defaults. Financial instabilities, economic turmoil, political crisis, exchange rate fluctuations, interest rate regimes, loan pricing strategies, and others are some of the main factors that increase the default risk of bank loans.

This paper basically investigates the bank loan approaches, the probability of credit defaults, and the differential treatment by banks in the region in granting loans. Sub-Saharan Africa region had undergone major reforms since1980s and 1990s. The reforms helped the banks to expand their traditional operations and international intermediation levels. Domestic and foreign investments in the region heavily relies on bank credits which in turn influences financial growth and economic stability. While banks strive to spear-up their overall performance, credits offered to public and private sectors affect their financial strength. Banks in SSA use a differential lending treatment to public and private sectors. The latter being given less attention, it seems that the economic and financial enhancement of the region has been negatively influenced due to such uneven treatments. The reluctance of the banks to lend to the private sector is due to their narrow risk bearing capabilities and lack of regional or domestic credit risk rating agencies. However, the banking system in the region has undergone significant changes over the past 25 years as explained by Beck and Cull (2013), financial liberalization and related banking reforms, upgrades in institutional and regulatory capacity, and expansion of cross-border banking activities with the rapid development of Pan-African banking groups' networks have significantly changed the African banking and financial landscapes.

Priced using different strategies and tagged with interest rates with underlying inflation and economic growth rates, bank loans are vital to support economic growth, financial stability, investments, and domestic and international monetary supply stability. Public and private banks intercept in the economy through offering credits to public and private sectors. Transforming loans to profitable credits without creating inflationary scenarios in the market is a vital task of banks. Loans are priced using different strategies that help to reflect the risk associated and the expected returns in the credit granting processes.

${ }^{1}$ The working paper of the International Monetary Fund of June 2010 followed a stochastic frontier analysis

${ }^{1}$ Source: IMF working paper - African Department Banking efficiency and Financial Development in SSA - prepared by Sandarine Kablan, 
to assess the banking efficiency stated that SSA banks are cost-efficient in producing their main outputs - deposits and short-term loans. Furthermore, the paper suggested efficiency could be improved by enhancing credit environment through better functioning judicial and legal processes and the accessibility of information on borrowers. Such enhancements could improve the effectiveness of banks in their financial intermediary role of transforming deposits into loans for investments. ${ }^{1}$ Emilio Sacerdoti (2005) showed that the stock of bank credit in SSA countries to the private sectors (including nonfinancial public enterprise) remain very low when compared with other developing countries. The only exceptions are South Africa and Mauritius which have well developed financial infrastructure. The financial intermediation in SSA countries remains low as measured by the ratio of broad money (M2) to GDP.

\section{Literature Review}

Bank loans in SSA countries are characterized by heavy regulatory framework that hinders international financial intermediation capacity and growth. Sandrine Kablan (2010) under the "Banking efficiency and financial development in Sub-Saharan Africa" argued the cost frontier relative to customer deposits is positive that an increase in production heightens bank costs. The elasticity of equity and loans in SSA showed negative result indicating the outputs are used as complementary products by SSA banks. Plamen Iossifov and May Khamis (2009) analyzed the credit growth in SSA banks and concluded that the countries in the region have experienced sustained expansion of credits to the private sector in recent years. Rapid credit growth generally entails prudential, macroeconomic, and balance sheet risks and policy responses would depend on the unfolding impact of the global recession and financial crisis on SSA credit markets.

Hipolyte Fofack (2005) investigated the lending causes of nonperforming loans during the economic and banking crisis of 1990s which affected large number of SSA countries. The empirical evidence of the study showed that there was a sustainable increase in nonperforming loans, high credit risk, and higher financial costs in SSA countries. In addition, the result of the study analyzed the strong causality between these loans and economic growth, real exchange rate appreciation, real interest rate, net interest margin, and inter-bank loans, consistent with the causality and economic analysis which revealed the significance of macro and microeconomic factors. IMF working paper prepared by Emilio Sacerdoti (2005) showed that the stock of bank credit in SSA countries to the private sector (including nonfinancial public enterprises) remain very low when compared with other developing countries. The only exceptions are South Africa and Mauritius which have well developed financial infrastructure. The financial intermediation in SSA countries remains low as measured by the ratio of broad money M2 to GDP. According to the study by Emilio Sacerdoti, in most SSA countries the ratio of M2 to GDP in 2003 was in the range of 15 to 30 percent, with only countries like South Africa, Mauritius, and Seychelles attained higher ratios for the given period. Furthermore, empirical evidence on credit risk management of the banks in the region has stated that Sub-Saharan Africa recovery from the crisis-induced slowdown is well underway, with growth in most of the countries in the region now back fairly close to the high level of the mid-2000s. Growth was expected to hit 5.5\% in 2011 and 6\% in 2012 (Regional Economic Outlook, Sub-Sahara Africa, Recovery and New Risk, April 2011). In addition, the International Monetary Fund working paper of May, 2009 prepared by Corrine Delchat, Gustavo Ramirez, Smita Wagh, and John Wakeman-Linn shows the integration of Sub-Saharan Africa to the Global Financial Markets under which the Banks play a major role by having a well-developed counterparty default management and expansion of risk bearing ability which eventually leads to more capital inflows and attract investors. Therefore, these banks are expected to behave in multi-directional ways; expanding lending ability, integrate with the global financial system, and more importantly enhance counterparty (credit) risk management.

Despite the overall global financial crisis of 2008, the countries in the SSA region have shown a substantial recovery ratio from their credit cramps. The ratio ranges from 5\% in 2010 to estimated ratio of $6 \%$ in 2012 . However, the banks in the region are still reluctant to lend out to the private sector mainly to SMEs and Individual investors. Different factors contribute to the reluctance of the banks to transform deposits to profit earning loans to the private sector. Large portion of capital goes to governments of the region which leaves a narrow room for the private sector to utilize loans. This has a negative and downward effect in investments. Insufficiency of capital for the purpose of private investment slows-down growth which in the long-run forces the economic and financial growth to be stagnant. Therefore, it is necessary to study the nature and size of the bank loans practiced, the default probabilities, the methodology of extending credit risk bearing capabilities without affecting the existing operations, introducing competitive loan pricing strategies, the differential treatment of credit granting technics, and creating credit risk management systems. 


\section{Methodology}

This study follows panel estimation techniques to analyze bank loans in SSA countries. The study examined bank credits approach, default probabilities, and differential credit treatment technics used in these banks. The key variable analyzed was bank credits by using domestic credit provided by banking sector to public and private sectors respectively as control variables. The sample has covered 16 selected countries across Sub-Saharan Africa region and has used annual data of 20 years (1991-2011). The parameters used are obtained from World Bank Development Indicators online database (WDI), Africa Development Bank (ADB), International Monetary Fund (IMF), International Financial Statistics (IFS), and Regional Economic Outlook. By mitigating the problems of spurious causality and unobserved heterogeneity, panel estimation techniques overcome common weaknesses of most cross-country approaches. Panel estimation techniques often give all countries, either small or large, an equal weighting since they are assumed to be homogeneous and the coefficients represent only average relationship, which may or may not apply to individual countries in the sample. Following Arellando and Bond (1991) and as later used by Christopoulous and Tsionas (2004), and Baltagi et al. (2008) a dynamic Generalized Method of Moments (GMM) is applied in the assessment. A dynamic panel estimator allows for the exploitation of time series variations in the data, accounts for unobserved country specific effects, allows for the inclusion of lagged variables as regressors, and controls for endogeneity of all explanatory variables. Hence, this basic dynamic panel model is estimated.

$\mathrm{y}_{\mathrm{it}}=\alpha+\beta_{1 \mathrm{i}} \mathrm{CR}_{\mathrm{it}}+\gamma_{\mathrm{i}} \mathrm{X}_{\mathrm{it}}+\varepsilon_{\mathrm{i}} \quad \mathrm{i}=1 \ldots, \mathrm{N} \quad \mathrm{t}=1 \ldots, \mathrm{T}$

To allow for possibility of partial adjustment, a dynamic log linear equation was specified below:

$\ln y_{\mathrm{it}}=\alpha+\beta_{1 \mathrm{i}} \ln \mathrm{CR}_{\mathrm{it}}+\gamma_{\mathrm{i}} \ln \mathrm{X}_{\mathrm{it}}+\varepsilon_{\mathrm{i}}$

Inclusion of new control variables to equation 1 gives an expanded model as follows:

$\operatorname{lny}_{\mathrm{it}}=\alpha+\gamma M \gamma-+\beta_{1 \mathrm{i}} \ln \mathrm{CR}_{\mathrm{it}}+\beta_{2 \mathrm{i}} \ln \mathrm{CG}_{\mathrm{it}}+\beta_{3 \mathrm{i}} \ln \mathrm{CPS}_{\mathrm{it}}+\beta_{4 \mathrm{i}} \ln \mathrm{DI}_{\mathrm{it}}+\beta_{5 \mathrm{i}} \ln \mathrm{DCPS}_{\mathrm{it}}+\beta_{6 \mathrm{i}} \ln \mathrm{LI}_{\mathrm{it}}+\varepsilon_{\mathrm{i}} \ldots \ldots \ldots \ldots \ldots . . . .$. (3)

\section{Results and Discussions}

\subsection{Summary statistics of variables}

${ }^{1}$ Table1: Summary Statistics of Variables

\begin{tabular}{|l|l|l|l|l|l|l|}
\hline Variables & Source & Unit of Measurement & Mean & Standard Deviation & Minimum & Maximum \\
\hline DCPBS & WDI & \% of GDP & 30.185 & 35.575 & -13.92 & 195.33 \\
\hline BM & WDI & \% of GDP & 22.544 & 19.221 & -47.85 & 84.61 \\
\hline CCG & WDI & \% of GDP & 8.524 & 42.818 & -413.7 & 389.796 \\
\hline CPS & WDI & \% of GDP & 10.702 & 26.946 & -22.11 & 471.45 \\
\hline DI & WDI & \% of GDP & 13.389 & 13.979 & 2.43 & 147.13 \\
\hline DCPS & WDI & \% of GDP & 20.088 & 29.187 & 2.01 & 161.98 \\
\hline LI & WDI & \% of GDP & 26.625 & 23.163 & 9 & 217.88 \\
\hline
\end{tabular}

Source: author's computation based on the data obtained from World Bank - WDI

The above statistical summary suggests that there exists a reasonable and significantly independent variation among the variables and the countries in the dataset. This allows and justifies the use of panel estimation techniques. The analysis includes 336 observations from the selected sample of 16 countries. A GMM estimator is applied in estimating the equation and generates the output. The integration and co-integration properties of the data are ignored and not important (Christopoulos and Tsionas, 2004). For each indicator of bank loans, a dynamic GMM is estimated. All the variables accounted for in table 1 were measured as percentage of GDP and Broad Money (BM).

\subsection{Bank Loans and Default Probabilities in SSA banks}

The research study estimates the sensitiveness of bank loans to default by considering the overall economic variables with annual data of 16 selected SSA countries of all categories for 20-year period covering from 19912011. To correct the correlated fixed effects and the endogeneity of regressors (Baltagi, 2005), a dynamic panel data estimator based on Generalized Method of Moments (GMM) is employed. The technique also allows the bank loan indicator to partially adjust to its long-run equilibrium values. The consistency of the estimates is premised on the assumption of lack of autocorrelation of the error terms. Specifically, there should be the rejection of the null hypothesis of the first order serial correlation and non-rejection of the second order. The study restricts the moment conditions to a maximum of two lags on the dependent variable to reduce the potential bias resulting from too many moment conditions while increasing the efficiency of the estimates.

To examine the approach and nature of bank loan in the sample SSA banks, Domestic Credit Provided by

\footnotetext{
${ }^{1}$ Author's computation. The variables in the table are independent variables to measure bank loans. The acronyms are as follows: BM $=$ Broad Money, CCG = Claims on Central Government, CPS = Claims on Private Sector, DCPS = Domestic Credit to Private Sector, DI = Deposit Interest rate, $\mathrm{LI}=$ Lending Interest rate
} 
Banking Sector (DCPBS) was used as a dependent variable. A statistical output explains that variables including Broad Money (BM) and Claims on Central Government (CCG) are positively correlated to DCPBS suggesting the availability of money within and outside the financial institutions affects bank loans provided to public and private sectors. Contraction of broad money in the markets restricts capital adequacy of banking institutions, forces fiscal policy measures, and significantly makes cost borrowings more expensive. The indicator was found significant at $5 \%$ significance level. The lower income and fragile economy in SSA countries observed such an outcome. However, broad money does not represent the capital only within banking institutions but also money outside the banking sector. Therefore, the indicator is a partial explanatory variable of the sensitiveness of bank loans. It was as expected that the CCG observed a positive correlation with significance level of 5\%. Governments in SSA countries heavily rely on their banks for financing their fiscal or capital budgets. In general, the results suggest that increase in Claims on central government will adversely affect the availability and liquidity of banks to provide sufficient amount of loans to the private sector.

Table 2: Summary of correlation coefficients and standard deviations of independent variables

\begin{tabular}{|l|l|l|l|l|l|l|}
\hline & BM & CCG & CPS & DCPS & DI & LI \\
\hline $\mathbf{r}$ & $0.026038^{* *}$ & $0.030644 * *$ & $0.005717 * * *$ & $1.189900 * *$ & $0.011847 * * *$ & $-0.079528 * * *$ \\
\hline$\sigma$ & $(0.020062)$ & $(0.036540)$ & $(0.039644)$ & $(0.029317)$ & $(0.118723)$ & $(0.046721)$ \\
\hline
\end{tabular}

Source: Author's statistical computation $(* * *, * * \& *$ indicate statistical significance at $1 \%, 5 \%, \& 10 \%$ levels respectively.)

Domestic credit provided by banking sector is positive and statistically significant at $1 \%$ and $5 \%$ level. The results of the coefficients show a strong evidence of a considerable persistence in the variable and slower speed of adjustment to shocks. This implies that bank credits provided by banking sector is influenced by other factors in the financial system. From the estimated coefficients for lagged domestic credit provided by banking sector we can see that comparatively the variable has the highest persistence with lowest speed of adjustment to shocks when Broad money is used to proxy domestic credit provided by banking sector. With domestic credit to private sector as a proxy of domestic credit provided by banking sector, the dependent variable shows relatively lower persistence and higher rate of adjustment to shocks.

The probability of defaults on bank loans can be measured by the amount of claims that a bank has mainly on the private sector of the economy. The same indicators were used to detect the degree of default risk faced by those banks with their credit lending operations. Despite its significance of influencing to the bank credits, the estimation proved that there exists low rate of default probabilities in the SSA banks for the reason that most of the banks are willing to lend to the central governments. In other words, lower coefficient of claims on the private sector explains that the banks in SSA countries are not willing to expand the risk bearing capabilities of providing sufficient amount of capital to the private sector. In addition to that, high government dependency on banks to finance annual budget deficits tends to increase the claims on central governments in SSA countries with a downside effect to credits to private sector. Thus, the ratio of bank credits to the private sector decreases at an increasing ratio of credits to the central government. However, the reluctance of banks in the region to actively participate in the private sector is explained not only by government reliance on banks for financing purposes but also the lack of proper credit rating agency in the region to indicate credit worthiness of private and institutional borrowers. The only exception in the analysis was recorded on South Africa, Seychelles, and Mauritius which have a well-developed financial institution in SSA region.

\subsection{Differential credit treatment in SSA banks}

To examine lending treatment of banks in the region to different customers, a closer policy outlook was taken in to consideration. Lending to the private sector is limited in SSA banks. The main reason for this as explained above is the excessive reliance of governments in those banks to finance their fiscal and capital budgets and high bureaucratic models. A strong evidence was found in the study that the banks possess sufficient capital reserves in their accounts. However, the degree transformation rate of those reserves in to productive loan assets, the degree of international financial intermediation, and accessibility and transparency rates in the region are relatively low with the exception of South Africa, Seychelles, and Mauritius. Therefore, the issue of liquidity and solvency was not an excuse for their reluctance to lending to the private sector. SMEs are less privileged business to access bank reserves. The key risk of SMEs, credit risk, is high SSA countries compared to those in developed countries. Those businesses remain expensive for banks to serve due to the risk level however, the lending rate is high to tradeoff such morale hazards. The study also has found out that the banks in the region are more accessible to foreign investors and foreign companies than to domestic markets. This is mainly due to lack of rating agencies actively engaged in rating local debtors of all kinds (the private sector including; institutional and individual investors, companies, and SMEs). 
Table 3: Bank claims and credits coefficients

\begin{tabular}{|l|l|l|l|l|}
\hline & CCG & CPS & DCPS & LI \\
\hline $\mathbf{r}$ & $0.123165^{*}$ & $-0.139217^{*}$ & $1.194279^{*}$ & $0.058736^{* *}$ \\
\hline$\sigma$ & $(0.014070)$ & $(0.03078)$ & $(0.024734)$ & $(0.035674)$ \\
\hline
\end{tabular}

$(* * *, * * \& *$ indicate statistical significance at $1 \%, 5 \%, \& 10 \%$ levels respectively. $)$

The low rate of financial inclusion of credits to private sector compared to claims on central government explains that the banks in SSA countries usually follow a differential treatment in lending credits. Domestic credits to private sector proved significant at $1 \%$ significance level. Claims on private sector was significant at $1 \%$ significance level with negative coefficients as expected. When lending interest rate was used as a control variable to prove this statement, it showed most SSA banks apply high lending rates to SMEs and individual borrowers compare to the rates they apply to central government borrowings to either safeguard their credits or to systematically discourage applicants. The variable-lending interest rate- was significant at 5\% significance level. The coefficients of Lending interest rate explain the fact that higher rates on borrowings can affect the intermediation ability of a bank to transform its deposits to loans and making its offers unattractive to investment. Higher lending rate is also a factor to cause and increase the credit risk (default probability) by making borrowers not responsive to comply with the pre-agreed contractual rates. In other words, the model of "risk based scientific pricing" is applied in generalization framework instead of categorization. The model states that based on historical credit data, high-risk category borrowers are to be priced high. This is adopting the "Risk Adjusted Return on Capital (RAROC)" framework. The risk rating models applied by SSA banks require significant revisions that would enable them to setup comprehensive risk scoring system on a given range of scales, clearly define rating thresholds and review ratings periodically preferably semi-annual intervals. The variations observed in the analysis partially explains why the target banks in the sample were reluctant to lend out to the private sector. The loan review mechanism (LRM) was another concern in the analysis. LRM is used to improve credit quality and to adjust credit audits of borrowers according to their credit worthiness. It targets all loans above certain cut-off limit ensuring that at least $30 \%-40 \%$ of the portfolio is subject to LRM in an annual basis to ensure that all major credit risks embedded in the balance sheet have been tracked. This mainly is carried out to bring qualitative credit administration, identifying credit weaknesses (failure to collect due credits), and determine adequacy of loan loss provisions. Table 4. shows the first four regression result of R2 of the dependent and independent variables. The R2 estimated using Panel Two Stage Least Squares (Panel 2SLS) to explain the variation of the dependent variable by the independent variable resulted in a strong evidence of explanatory result.

Table 4: Statistical Regression Results Dependent Variable: Domestic Credit Provided by Banking Sector (DCPBS) Method: Panel Generalized Method of Moments (GMM)

\begin{tabular}{|l|l|l|l|l|}
\hline \multirow{2}{*}{ Variables } & $\begin{array}{l}\text { Dependent Variable: Domestic Credit Provided by Banking Sector } \\
(\mathrm{DCPBS})\end{array}$ \\
\cline { 2 - 5 } & Regression No. \\
\hline & $(1)$ & $(2)$ & $(3)$ & $(4)$ \\
\hline Constant $(\alpha)$ & $0.588125^{* *}$ & $0.360494 * *$ & $-0.031499 * * *$ & $-0.037039 * * *$ \\
& $(0.073578)$ & $(0.080522)$ & $(0.082090)$ & $(0.080336)$ \\
\hline $\mathrm{R}^{2}$ & 0.928274 & 0.925659 & 0.909220 & 0.908941 \\
\hline $\begin{array}{l}\text { Wald test of joint significance- } \\
\text { probability }\end{array}$ & $(0.00)$ & $(0.00)$ & $(0.00)$ & $(0.00)$ \\
\hline
\end{tabular}

Source: Author's computation

\subsection{Robustness of results}

To check the sensitivity of the results to alternative panel estimation technique, a robustness check was conducted by estimating the regressions with Panel Two Stage Least Squares (Panel 2SLS) fixed effect estimation with robust standard errors. The results are presented in table 5. Domestic credit provided by banking sector exhibited a positive coefficient in all the regressions made using Panel 2SLS at 1\%, 5\%, and 10\% significance levels.

Table 5: Robustness results variables

\begin{tabular}{|l|l|l|l|l|l|l|}
\hline & BM & CCG & CPS & DCPS & DI & LI \\
\hline $\mathbf{r}$ & $0.041337^{* *}$ & $0.123165^{*}$ & $-0.139217^{*}$ & $1.194279^{*}$ & $0.072208^{* *}$ & $0.167025^{*}$ \\
\hline$\sigma$ & $(0.037249)$ & $(0.014070)$ & $(0.03078)$ & $(0.024734)$ & $(0.092874)$ & $(0.057861)$ \\
\hline
\end{tabular}

Source: Author's statistical computation $(* * *, * * \& *$ indicate statistical significance at $1 \%, 5 \%, \& 10 \%$ levels respectively.)

$\mathrm{R}^{2}$ was estimated using Panel Two Stage Least Squares (Panel 2SLS) to explain the variation of the dependent variable by the independent variable also resulted in a strong evidence of explanatory result. All independent variables in the analysis observed almost the same degree of coefficients and variations that explain the variables 
used were capable of explaining bank credits in SSA banks. Furthermore, the robustness test results showed the countries in the sample observed similar variations in their bank loans. The exceptions were South Africa, Seychelles, and Mauritius which has better banking system and well-developed financial institutions. Table 6 shows the estimated results.

Table 6: Robustness check Regression Output

Dependent Variable: Domestic Credit Provided by Banking Sector (DCPBS) Method: Panel Generalized Method of Moments (GMM)

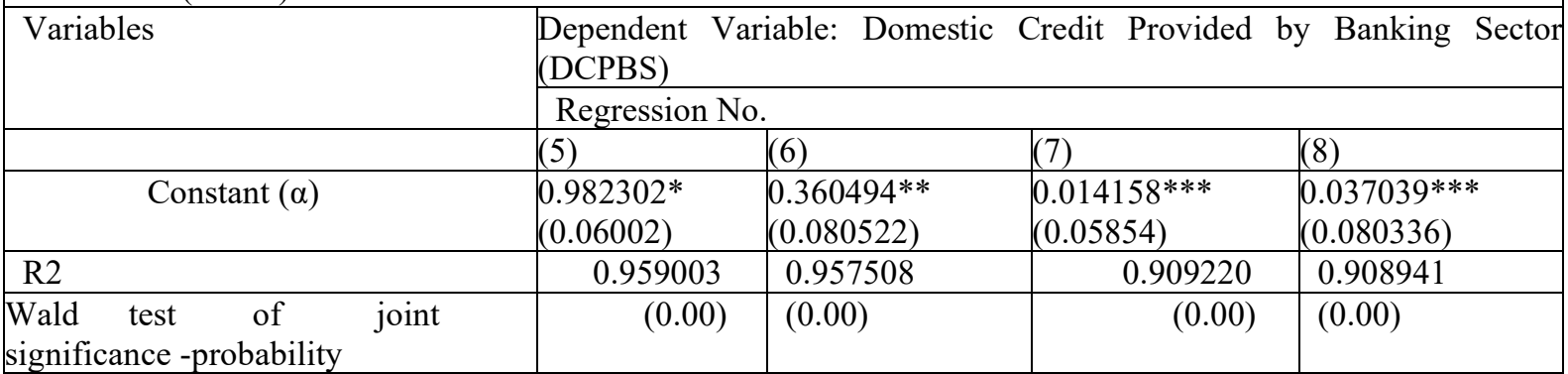

Source: Author's computations

\section{Conclusion}

Bank credits are vital for economic consumption and growth. Private investments can be enhanced through bank credits. SMEs and individual investors rely on bank loans for investments and growth. Banking industry in SSA countries require evolutionary steps from being highly regulated into more open and accessible system. Access to credit is a crucial step for economic growth and financial stability. Default risks can be significantly lowered by using appropriate risk tackling mechanism and creation of proper credit rating agencies in the region. Besides, the banking system should be able to introduce non-differential credit granting treatment having all requirements being met dully. In general, the results suggest that increase in Claims on central government adversely affects the availability and liquidity of banks to provide sufficient amount of loans to the private sector. This result is in line with the findings of Sandarine Kablan June 2010 which advocates that despite the large deposits acquired, SSA banks have smaller intermediation ratio (claims on the private sector relative to total deposits) when compared to other developing countries. This implies that the SSA banks have their greater portion of credits held by the central governments thereby narrowing the openness and expansion of credits to the private sector. As most of SSA governments depend on banks to finance budget deficits, banks become unable to freely intercept in the private investment sectors and international financial intermediation.

\section{References}

Emilio Sacerdoti, (2005). Access to Bank Credit in Sub-Saharan Africa: Key Issues and Reform Strategies. IMF working paper (WP/05/166) - Monetary and Financial System Department.

Sandrine Kablan, (2010). Banking Efficiency and Financial Development in Sub-Saharan Africa. IMF Working paper (WP/10/136) - African Department.

Iftekhar Hasan, Cristiano Zazzara, (2006). Pricing Risky Bank Loans in the new Basel II Environment. Bank of Finland Research Discussion Papers.

George S. Oldfield, Anthony M. Santomero, (2010). The Place of Risk Management in Financial Institutions. Wharton Financial Institutions Center.

David Ruthenberg, Yoram Landskroner, (2007). Loan Pricing under Basel II in an Imperfectly Competitive Banking Market. Basel II working paper 07.05.

Wolfgang Bauer, Marc Ryser, (2003). Risk Management Strategies for Banks. Elsevier Journal of Banking and Finance.

R.S Raghavan, (2003). Risk Management in Banks. Chartered Accountant pp 842-843, pp 845.

Robert S. Pindyck, Daniel L. Rubinfeld, (1998). Econometric Models and Economic Forecasts. Fourth Edition McGraw Hill.

Berg, Andrew, Norbert Funke, Alejandro Hajdenberg, Victor Duarte Lledo, Rolando Ossowski, Martin Schindler, Antonio Spilimbergo, Shamsuddin Tareq, and Irene Yackovlev, (2009). Fiscal Policy in Sub-Saharan Africa in Response to the Impact of the Global Crisis. Regional Economic Outlook - African Department- SubSaharan Africa WP/09/10.

Singh, Raju Jan, and Yifei Huang, (2011). Financial Deepening, Property Rights and Poverty: Evidence from SubSaharan Africa. Regional Economic Outlook - African Department, Sub-Saharan Africa WP/11/196.

Lledo, Victor Duarte, and Marcos Poplawski Ribeiro, (2011). Fiscal Policy Implementation in Sub-Saharan Africa.Regional Economic Outlook - African Department, Sub-Saharan Africa WP/11/172.

Deleehat, Corinne, Gustavo Ramirez, Smita Wagh, and John Wakeman-Linn, (2009). Sub-Saharan Africa's 
Integration in the Global Financial Markets. Regional Economic Outlook - African Department, SubSaharan Africa WP/09/194.

Chen, Chuling, (2009). Bank Efficiency in Sub-Saharan African Middle-Income Countries. Regional Economic Outlook - African Department - Sub-Saharan Africa WP/09/14.

J. Christensen, (2004). Domestic Debt Markets in Sub-Saharan Africa. IMF Working Paper 04/46 (Washington: International Monetary Fund).

Markus K. Brunnermeier, (2009). Deciphering the Liquidity and Credit Crunch 2007-2008. Journal of Economic Perspectives_-Volume 23, Number 1-winter 2009-Pages 77-100.

S.M. Ali Abbas, Nazim Belhocine, Asmaael-Ganainy, and Mark Horton, (2011). Historical Patterns and Dynamics of Public Debt_Evidence from a New Database. IMF Economic Review Vol. 59, No. 4. 